\title{
Membranous nephropathy associated with multicentric Castleman's disease that was successfully treated with tocilizumab: a case report and review of the literature
}

Ryosuke Saiki ${ }^{1}$, Kan Katayama ${ }^{1 *}$ (D, Y Yosuke Hirabayashi ${ }^{1}, K^{2}$ iko Oda ${ }^{1}$, Mika Fujimoto ${ }^{1}$, Tomohiro Murata ${ }^{1}$, Ayako Nakajima ${ }^{2}$ and Kaoru Dohi ${ }^{1}$

\begin{abstract}
Background: Multicentric Castleman's disease is a life-threatening disorder involving a systemic inflammatory response and multiple organ failure caused by the overproduction of interleukin-6. Although renal complications of Castleman's disease include AA amyloidosis, thrombotic microangiopathy, and membranoproliferative glomerulonephritis, membranous nephropathy is relatively rare. We experienced a case of secondary membranous nephropathy associated with Castleman's disease.

Case presentation: The patient was a 43-year-old Japanese man who had shown a high zinc sulfate value in turbidity test, polyclonal hypergammaglobulinemia, anemia, and proteinuria. A physical examination revealed diffuse lymphadenopathy, an enlarged spleen and papulae of the body trunk. A skin biopsy of a papule on the patient's back showed plasma cells in the perivascular area and he was diagnosed with multicentric Castleman's disease, plasma cell variant. Kidney biopsy showed the appearance of bubbling in the glomerular basement membranes in Periodic acid methenamine silver stain and electron microscopy revealed electron dense deposits within and outside the glomerular basement membranes. Since immunofluorescence study showed predominant granular deposition of $\lg G 1$ and $\operatorname{lgG} 2$, he was diagnosed with secondary membranous nephropathy associated with Castleman's disease. He was initially treated with prednisolone alone, however his biochemical abnormalities did not improve. After intravenous tocilizumab (700 mg every 2 weeks) was started, his C-reactive protein elevation, anemia, and polyclonal gammopathy improved. Furthermore, his urinary protein level declined from $1.58 \mathrm{~g} / \mathrm{gCr}$ to $0.13 \mathrm{~g} / \mathrm{gCr}$. The prednisolone dose was gradually tapered, then discontinued. He has been stable without a recurrence of proteinuria for more than 6 months.
\end{abstract}

Conclusions: Tocilizumab might be a treatment option for secondary membranous nephropathy associated with Castleman's disease.

Keywords: Castleman's disease - membranous nephropathy, Proteinuria - tocilizumab

\footnotetext{
* Correspondence: katayamk@clin.medic.mie-u.ac.jp

'Department of Cardiology and Nephrology, Mie University Graduate School of Medicine, 2-174 Edobashi, Tsu, Mie 514-8507, Japan

Full list of author information is available at the end of the article
}

(c) The Author(s). 2021 Open Access This article is licensed under a Creative Commons Attribution 4.0 International License, which permits use, sharing, adaptation, distribution and reproduction in any medium or format, as long as you give appropriate credit to the original author(s) and the source, provide a link to the Creative Commons licence, and indicate if changes were made. The images or other third party material in this article are included in the article's Creative Commons licence, unless indicated otherwise in a credit line to the material. If material is not included in the article's Creative Commons licence and your intended use is not permitted by statutory regulation or exceeds the permitted use, you will need to obtain permission directly from the copyright holder. To view a copy of this licence, visit http://creativecommons.org/licenses/by/4.0/ The Creative Commons Public Domain Dedication waiver (http://creativecommons.org/publicdomain/zero/1.0/) applies to the data made available in this article, unless otherwise stated in a credit line to the data. 


\section{Background}

Castleman's disease (CD) consists of a lymphoproliferative disorder that was first reported by Castleman et al. [1]. CD is classified into two types: unicentric CD (UCD) and multicentric CD (MCD). While UCD is thought to be a benign disease because curative resection is possible for most patients [2], MCD is a life-threatening disorder involving a systemic inflammatory response and multiple organ failure caused by the overproduction of interleukin-6 (IL-6) [3]. Previous studies have shown that renal complications of CD mainly include AA amyloidosis, thrombotic microangiopathy (TMA), and membranoproliferative glomerulonephritis (MPGN) [4, 5]. The treatment of renal complications of $\mathrm{CD}$ has not been clarified. We

Table 1 Laboratory data before the kidney biopsy

\begin{tabular}{|c|c|c|c|}
\hline Urinary examination & - & Blood chemistry & - \\
\hline $\mathrm{pH}(4.5-7.5)$ & 7 & $\mathrm{HbA} 1 \mathrm{c}(\%, 4.9-6.0)$ & 6.1 \\
\hline Protein $(\mathrm{g} / \mathrm{gCr})$ & 1.43 & TP (g/dl, 6.6-8.1) & 11.7 \\
\hline Occult blood & $(3+)$ & Alb (g/dl, 4.1-5.1) & 2.6 \\
\hline Glucose & $(-)$ & BUN (mg/dl, 8-20) & 13.6 \\
\hline$\beta_{2} M G(\mu g / l, 5-253)$ & 253 & $\mathrm{Cr}(\mathrm{mg} / \mathrm{dl}, 0.65-1.07)$ & 0.77 \\
\hline \multirow[t]{2}{*}{ NAG (IU/I, 1.0-4.2) } & \multirow[t]{2}{*}{22.1} & eGFR $\left(\mathrm{ml} / \mathrm{min} / 1.73 \mathrm{~m}^{2}\right)$ & 87.7 \\
\hline & & UA (mg/dl, 3.7-7.8) & 5.6 \\
\hline Complete blood count & - & $\mathrm{Na}(\mathrm{mEq} / \mathrm{l}, 138-145)$ & 136 \\
\hline WBC $(/ \mu \mathrm{l}, 3300-8600)$ & 7600 & $\mathrm{~K}(\mathrm{mEq} / \mathrm{l}, 3.6-4.8)$ & 4.1 \\
\hline $\mathrm{RBC}\left(\times 10^{4} / \mu \mathrm{l}, 435-555\right)$ & 413 & $\mathrm{Cl}(\mathrm{mEq} / \mathrm{l}, 101-108)$ & 103 \\
\hline $\mathrm{Hb}(\mathrm{g} / \mathrm{dl}, 13.7-16.8)$ & 10 & $\mathrm{Ca}(\mathrm{mg} / \mathrm{dl}, 8.8-10.1)$ & 8.5 \\
\hline \multirow[t]{2}{*}{ Plt $\left(\times 10^{4} / \mu \mathrm{l}, 15.8-34.8\right)$} & \multirow[t]{2}{*}{37.1} & IP (mg/dl, 2.7-4.6) & 3.4 \\
\hline & & AST (U/I, 13-30) & 10 \\
\hline Serology & - & $\operatorname{ALT}(U / I, 10-42)$ & 7 \\
\hline ANA & $1: 40$ & LDH (U/I, 124-222) & 102 \\
\hline MPO-ANCA (U/ml, 0-8.9) & 2.5 & үGTP (U/l, 13-64) & 13 \\
\hline Anti-SS-A (U/ml, 0-7.0) & 1.3 & CRP (mg/dl, 0-0.14) & 7.65 \\
\hline Anti-SS-B (U/ml, 0-7.0) & 2.1 & $\operatorname{lgG}(\mathrm{mg} / \mathrm{dl}, 861-1747)$ & 6940 \\
\hline $\mathrm{SAA}(\mu \mathrm{g} / \mathrm{ml}, 0-8)$ & 1300 & $\operatorname{lgA}(\mathrm{mg} / \mathrm{dl}$, 93-393) & 543 \\
\hline $\mathrm{IL}-6(\mathrm{pg} / \mathrm{ml}, 0-4.0)$ & 15.5 & $\operatorname{lgM}(\mathrm{mg} / \mathrm{dl}, 33-183)$ & 429 \\
\hline geniQ HHV8 (copy/ml, $\left.0-2 \times 10^{2}\right)$ & undetectable & C3 (mg/dl, 73-138) & 131 \\
\hline \multirow[t]{4}{*}{ HIV antibody (S/CO, 0-1.00) } & \multirow[t]{4}{*}{0.07} & $\mathrm{C} 4$ (mg/dl, 11-31) & 18.1 \\
\hline & & CH50 (U/ml, 31.6-57.6) & 49 \\
\hline & & Ferritin (ng/ml, 50-200) & 102.6 \\
\hline & & slL-2 R (U/ml, 122-496) & 1276 \\
\hline
\end{tabular}

Alb Albumin, ALT Alanine transaminase, ANA Antinuclear antibody, Anti-SS-A SSA antibodies, Anti-SS-B SSB antibodies, AST Asparate transaminase, $\beta 2 M G \beta 2$ microglobulin, $B U N$ Blood urea nitrogen, $C 3$ Complement 3, C4 Complement 4, $\mathrm{Ca}$ Calcium, $\mathrm{CH} 50$ 50\% hemolytic complement activity, $\mathrm{Cl}$ Chloride, $\mathrm{Cr}$ Creatinine, CRP C-reactive protein, eGFR Estimated glomerular filtration rate, $\gamma G T P$ p-glutamyltranspeptidase, $H b$ hemoglobin, $H b A 1 c$ Hemoglobin A1c, $\mathrm{HCO}_{3}{ }^{-}$Bicarbonate ion, $\mathrm{HHV} 8$ human herpesvirus 8, HIV Human Immunodeficiency Virus, IgA Immunoglobulin A, IgG Immunoglobulin G, IgM Immunoglobulin M, IL-6 Interleukin-6, IP Inorganic phosphate, $K$ Kalium, LDH Lactate dehydrogenase, MPO-ANCA Myeloperoxidase antineutrophil cytoplasmic antibody, Na Natrium, NAG N-acetyl- $\beta$-D-glucosaminidase, $\mathrm{Plt}$ Platelets, $R B C$ Red blood cells, SAA Serum amyloid A, sIL-2 Soluble interleukin-2 receptor, TP Total protein, UA Uric acid, WBC White blood cells herein report a case of secondary membranous nephropathy $(\mathrm{MN})$ associated with $\mathrm{CD}$ that was successfully treated with tocilizumab.

\section{Case presentation}

The patient was a 43-year-old Japanese man who had shown a high zinc sulfate value in turbidity test in a

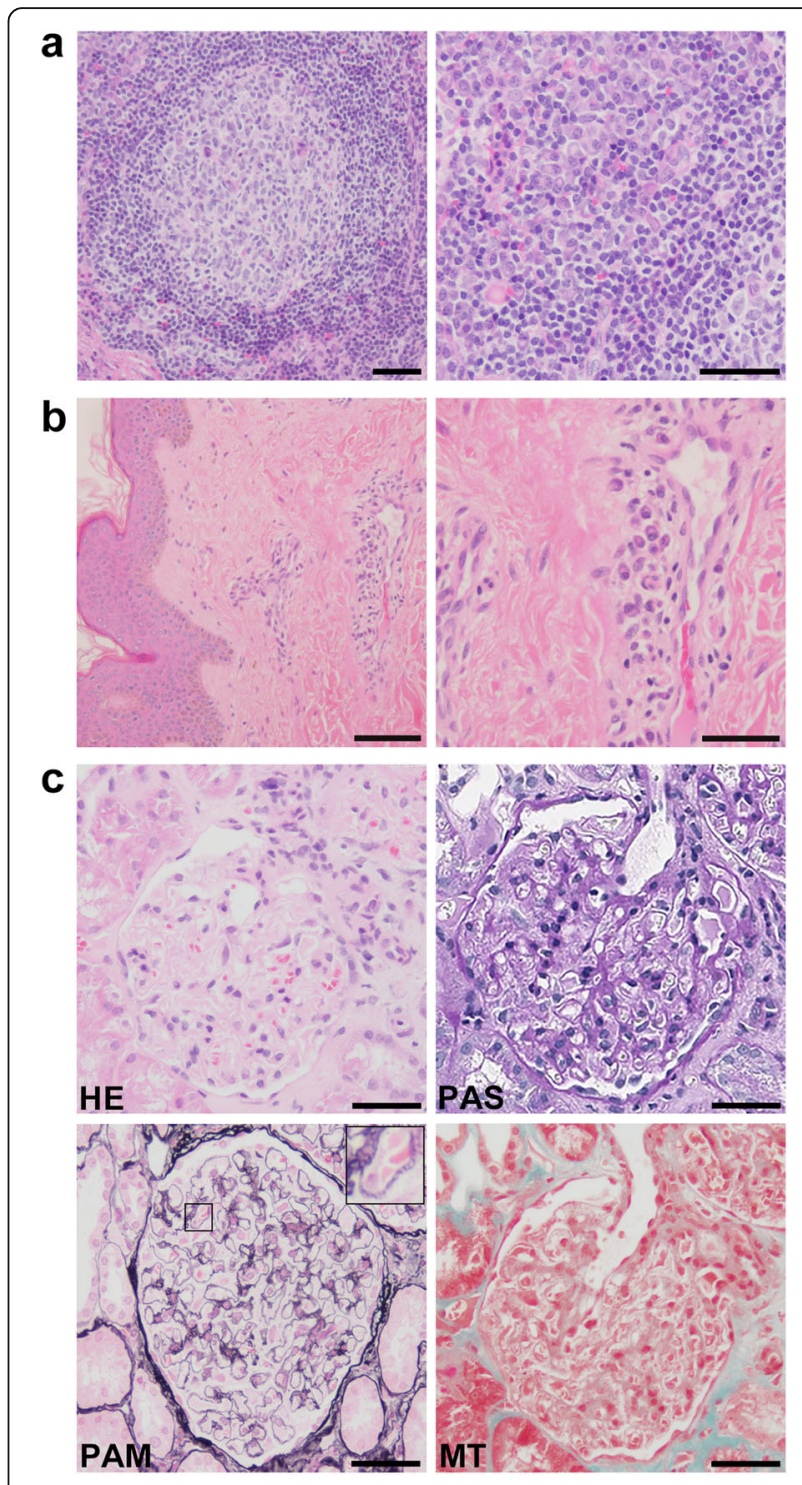

Fig. 1 Light microscopy. a A submental lymph node biopsy showed diffuse interfollicular plasma cell infiltration (Hematoxylin and eosin staining [HE]). Left panel: Bar $=50 \mu \mathrm{m}$, Right panel: $\mathrm{Bar}=50 \mu \mathrm{m}$. b Skin biopsy showed plasma cells in the perivascular area (HE). Left panel: $\mathrm{Bar}=250 \mu \mathrm{m}$, Right panel: Bar $=100 \mu \mathrm{m}$. c Kidney biopsy findings. HE staining showed no sign of inflammatory cell infiltration in the glomeruli. Periodic acid Schiff (PAS) staining showed no signs of mesangial proliferation, crescents, or adhesion. Periodic acid methenamine silver (PAM) staining showed the appearance of bubbling (enlarged rectangle) in the glomerular basement membranes. Masson-Trichrome (MT) staining showed no sign of immune complex deposits in the glomeruli. Bars $=50 \mu \mathrm{m}$ 
health checkup 4 years previously. He was examined by a local doctor who pointed out hypergammaglobulinemia and anemia. He had taken colchicine and febuxostat to treat gout 3 years previously. After presenting mild hematuria and proteinuria 2 years previously, he was referred to our hospital for further examination and treatment. The patient's height was $170 \mathrm{~cm}$, and his body weight was $85 \mathrm{~kg}$. His blood pressure was 129/83 mmHg, his pulse was 95 beats/minute, and his body temperature was $36.2^{\circ} \mathrm{C}$. He sometimes experienced night sweat. A physical examination revealed diffuse lymphadenopathy, an enlarged spleen and papulae of the body trunk. The laboratory data are shown in Table 1 . There was no monoclonal peak on immunoelectrophoresis in serum and urine tests. Renal ultrasound showed that the kidneys were of normal size, with normal renal arterial resistive indices. Computed tomography of the chest, abdomen, and pelvis showed cervical, axillary, and paraaortic lymphadenopathies and splenomegaly.

An excisional submental lymph node biopsy showed diffuse interfollicular plasma cell infiltration (Fig. 1a). Immunohistochemistry revealed neither interfollicular plasmacytosis nor laterality of the $\kappa$ or $\lambda$ light chains. IgG4-positive cells were detected, but the IgG4/IgG ratio was $<0.1$. A skin biopsy of a papule on the patient's back showed plasma cells in the perivascular area (Fig. 1b). The patient was diagnosed with MCD, plasma cell variant.

Kidney biopsy revealed 2 instances of global sclerosis in 19 glomeruli. Hematoxylin and eosin (HE) staining showed that there was no inflammatory cell infiltration in the glomeruli (Fig. 1c). Periodic acid Schiff (PAS) staining showed no signs of mesangial proliferation, crescents, or adhesion (Fig. 1c). Periodic acid

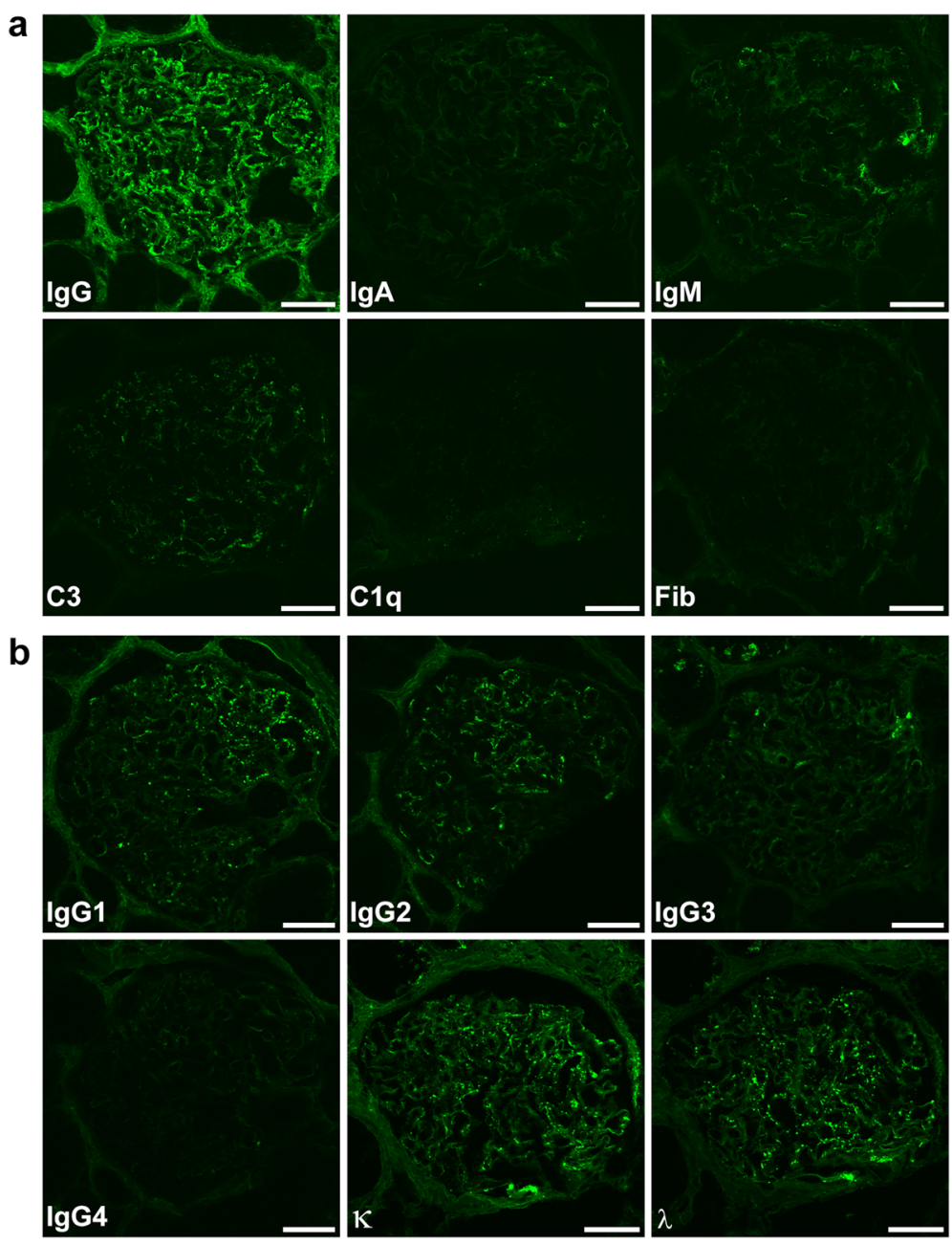

Fig. 2 Immunofluorescence study. a Immunofluorescence showed strong focal granular staining for IgG and weak focal granular staining for C3 along the glomerular basement membranes. Immunofluorescence showed no signs of IgA, IgM, C1q or Fib. Bars $=50 \mu \mathrm{m}$. b lgG subclass staining was composed of predominantly $\lg G 1$ and $\lg G 2$, not $\lg G 4$. Bars $=50 \mu \mathrm{m}$. There was no major difference in staining between the $\mathrm{k}$ and $\lambda$ chains. Bars $=50 \mu \mathrm{m}$ 


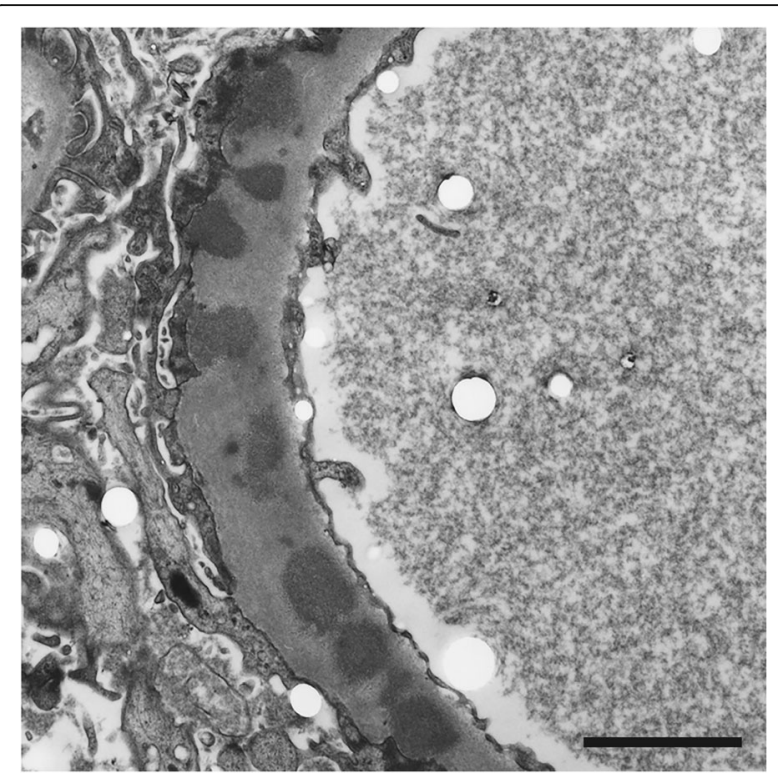

Fig. 3 Electron microscopy. Electron dense deposits were observed within glomerular basement membranes. This was classified as Ehrenreich-Churg stage III. Bar $=2 \mu \mathrm{m}$

methenamine silver (PAM) staining showed the appearance of bubbling in the glomerular basement membranes (Fig. 1c). Masson-Trichrome (MT) staining demonstrated the absence of immune complex deposits in the glomeruli (Fig. 1c). Immunofluorescence showed the focal granular deposition of IgG and C3 along the glomerular basement membranes (Fig. 2a). The IgG deposits were predominantly composed of IgG1 and IgG2, but not IgG4, suggesting secondary MN rather than primary MN (Fig. 2b). Anti-phospholipase A2 receptor antibodies were not measured. There was no big difference in staining between $\mathrm{k}$ and $\lambda$ chains (Fig. 2b). Direct fast scarlet staining was negative. Electron microscopy revealed electron dense deposits within and outside the glomerular basement membranes (Fig. 3). Based on these results, the patient was diagnosed with secondary MN.

The patient was initially treated with prednisolone alone; however, his biochemical abnormalities did not improve. Thus, intravenous tocilizumab (700 mg every 2 weeks) was started. After treatment with tocilizumab, the patient's C-reactive protein (CRP) elevation, anemia, and polyclonal gammopathy improved (Fig. 4). Furthermore, his urinary protein level declined from $1.58 \mathrm{~g} / \mathrm{gCr}$ to $0.13 \mathrm{~g} / \mathrm{gCr}$. The prednisolone dose was gradually tapered, then discontinued. He has been stable without a recurrence of proteinuria for more than 6 months.

\section{Discussion and conclusions}

We experienced a rare case of $\mathrm{MN}$ that was associated with MCD. The patient's high zinc sulfate level was considered to be related to $\mathrm{CD}$. In a kidney biopsy specimen, PAM staining revealed a bubbling appearance in

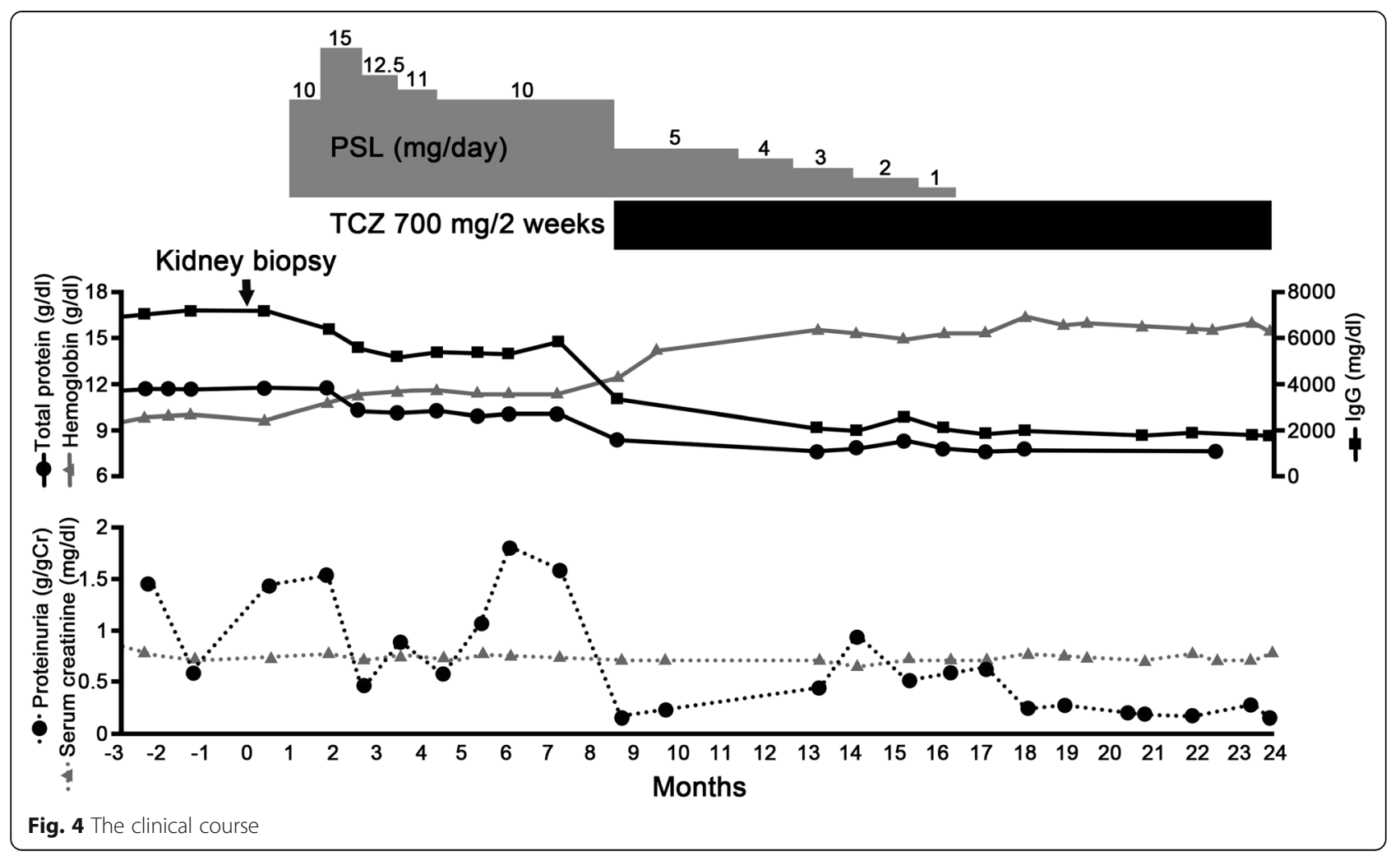


Table 2 Summary of reported cases of membranous nephropathy associated with Castleman's disease

\begin{tabular}{|c|c|c|c|c|c|c|c|c|c|c|c|}
\hline & Article & Age & Sex & $\begin{array}{l}\text { TP } \\
\text { (g/dl) }\end{array}$ & $\begin{array}{l}\text { Alb } \\
(g / d l)\end{array}$ & $\begin{array}{l}\mathrm{Cr} \\
(\mathrm{mg} / \mathrm{dl})\end{array}$ & $\begin{array}{l}\text { VEGF } \\
(\mathrm{pg} / \mathrm{ml})\end{array}$ & $\begin{array}{l}\text { IL-6 } \\
\text { (pg/ml) }\end{array}$ & $\begin{array}{l}\text { CRP } \\
\text { (mg/dl) }\end{array}$ & $\begin{array}{l}\operatorname{lgG} \\
(\mathrm{mg} / \mathrm{dl})\end{array}$ & $\begin{array}{l}\text { Proteinuria } \\
\text { (g/day) }\end{array}$ \\
\hline 1 & Weisenburger 1979 & 51 & M & 6.8 & 0.8 & 1.3 & NA & NA & NA & 2960 & 10 \\
\hline 2 & Ruggieri 1990 & 15 & $\mathrm{~F}$ & 5 & 2.1 & NA & NA & NA & NA & 300 & 20 \\
\hline 3 & Komaba 2008 pat 1 & 46 & M & 11 & 2 & 0.65 & NA & 23.8 & 8.8 & 6070 & 1 \\
\hline 4 & Tazi 2012 & 45 & M & NA & 1.9 & 0.69 & NA & NA & 12 & NA & 7.2 \\
\hline 5 & Xu 2012 pat 15 & 56 & M & NA & 2.28 & NA & NA & NA & 14.8 & NA & NA \\
\hline 6 & Sun 2020 pat 12 & 44 & M & NA & NA & NA & 89.2 & NA & NA & NA & NA \\
\hline 7 & Furutera 2020 pat 1 & 58 & M & 8.7 & 2.1 & 1.2 & NA & 36 & 8.6 & 4156 & $4.4(\mathrm{~g} / \mathrm{gCr})$ \\
\hline 8 & The present case & 43 & M & 11.7 & 2.6 & 0.71 & 467 & 15.5 & 7.65 & 6940 & $1.43(\mathrm{~g} / \mathrm{gCr})$ \\
\hline
\end{tabular}

Alb Albumin, Cr Creatinine, CRP C-reactive protein, F Female, IgG Immunoglobulin G, IL-6 Interleukin-6, M Man, NA Not available, pat Patient, TP Total protein, VEGF Vascular endothelial growth factor

the glomerular basement membranes and electron microscopy revealed electron dense deposits within and outside the glomerular basement membranes; these findings were compatible with a diagnosis of MN. Since the IgG depositions were predominantly composed of IgG1 and IgG2, the MN in the present case was thought to be secondary rather than primary.

Regarding renal complications of $\mathrm{CD}, 9-71 \%$ of $\mathrm{CD}$ patients are reported to have elevated creatinine or blood urea nitrogen [6]. Another report showed that 19 of $76 \mathrm{CD}$ patients $(25 \%)$ had renal involvement and that the most common etiology was TMA-like lesions [7]. Several studies reported that the renal histology of $C D$ mainly included AA amyloidosis, TMA, and MPGN [4, 5]. CD-associated AA amyloidosis might be caused by the overproduction of IL- 6 because IL- 6 was reported to play a critical role in the synergistic induction of the human SAA gene [8]. With respect to $\mathrm{CD}$-associated renal TMA, Mutneja et al. reported that the VEGF expression in podocytes was decreased despite there being a high level of VEGF in circulation [9]. Since the local reduction of VEGF within the kidney was reported to be sufficient to trigger the pathogenesis of TMA in adult mice [10], CD-associated renal TMA might be caused by the downregulation of VEGF in podocytes. Regarding CDassociated MPGN, the exact mechanism through which CD leads to MPGN remains unknown; however, MPGN related to CD might be secondary to chronic TMA [11].

We searched the PubMed database for relevant studies using the following search term: "castleman kidney" or "castleman membranous nephropathy" or "membranous nephropathy angiofollicular lymph node hyperplasia". CD-associated MN was rare, in addition to the present case, only 7 cases were identified in the relevant English literature (Table 2) [7, 12-17]. Among the 8 reported cases (including the present case), seven patients were male; only one patient was female. All patients who were tested had high serum levels of VEGF, IL-6, and CRP.

Table 3 Summary of the outcomes of the reported cases

\begin{tabular}{|c|c|c|c|c|c|c|c|}
\hline & Article & LN & Renal phenotype & Renal histological type & Treatment & Renal outcomes & $\begin{array}{l}\text { Patient } \\
\text { outcomes }\end{array}$ \\
\hline 1 & Weisenburger 1979 & NA & NS & MN & Symptomatic treatment & NA & NA \\
\hline 2 & Ruggieri 1990 & $\mathrm{HV}$ & NS & MN & $\begin{array}{l}\text { Lymphadenectomy, CY, } \\
\text { Indomethacin }\end{array}$ & $\begin{array}{l}\text { Complete } \\
\text { remission }\end{array}$ & Survive \\
\hline 3 & Komaba 2008 pat 1 & Mixed & Mild proteinuria & $\begin{array}{l}\text { MN (IgG2 positive), } \\
\text { Localized IN }\end{array}$ & PSL, TCZ & $\begin{array}{l}\text { Proteinuria } \\
<0.5 \mathrm{~g} / \text { day }\end{array}$ & Survive \\
\hline 4 & Tazi 2012 & $\mathrm{HV}$ & NS & MN & PSL & Complete remission & Survive \\
\hline 5 & Xu 2012 pat 15 & PC & $\begin{array}{l}\text { Hematuria, NS, ARF, } \\
\text { RPGN }\end{array}$ & $C G, M N$ & $\mathrm{R}-\mathrm{CHOP}, \mathrm{HD}, \mathrm{PE}$ & $\begin{array}{l}\text { Chronic renal } \\
\text { failure }\end{array}$ & Survive \\
\hline 6 & Sun 2020 pat 12 & NA & NA & ATIN, MN & PSL, CY, Thalidomide, CyA & Normalized & Survive \\
\hline 7 & Furutera 2020 pat 1 & PC & NS & $C G, M N$ & PSL, TCZ & $\begin{array}{l}\text { Complete } \\
\text { remission }\end{array}$ & Survive \\
\hline 8 & The present case & PC & Mild proteinuria & MN & PSL, TCZ & $\begin{array}{l}\text { Complete } \\
\text { remission }\end{array}$ & Survive \\
\hline
\end{tabular}

ATIN Acute tuburointerstitial nephritis, ARF Acute renal failure, CG Crescentic glomerulonephritis, CY Cyclophosphamide, CyA Cyclosporin A, HD Hemodialysis, HV Hyaline-vascular type, IN Interstitial nephritis, LN Lymph node, Mixed Mixed type, MN Membranous nephropathy, NA Not available, NS Nephrotic syndrome, pat Patient, $P C$ Plasma cell type, PE Plasma exchange, PSL Prednisolone, $R$-CHOP rituximab, cyclophosphamide, adriamycin, vincristine, and prednisolone, $R P G N$ Rapidly progressive glomerulonephritis, TCZ Tocilizumab 
Six patients experienced proteinuria. The histopathological patterns of the 8 cases were as follows: hyalinevascular (HV) type, $n=2$; plasma-cell type, $n=3$; mixed type, $n=1$; and unknown type, $n=2$ (Table 3). Six of the 8 cases had favorable renal outcomes. Only case 1 experienced acute kidney injury, resulting in chronic renal failure. The treatment options varied.

Previous reports suggested the efficacy of tocilizumab in reducing proteinuria as a renal complication of $C D$ $[14,17,18]$. There were three cases of MN caused by $\mathrm{CD}$, including the present case, that were treated with tocilizumab (Table 3). Komaba et al. [14]. reported a case of mixed-type CD that was treated with tocilizumab while the case reported by Furutera et al. [17] and the present case were plasma cell-type $\mathrm{CD}$. Although it has not been clarified why $\mathrm{CD}$ causes $\mathrm{MN}$, the reduction of proteinuria in $\mathrm{CD}$-associated $\mathrm{MN}$ by tocilizumab, which is an IL-6 receptor antagonist, suggests that CDassociated MN might be related to IL-6. While he has been stable without recurrence of proteinuria for more than 6 months, a longer follow-up period is needed, as the proteinuria in the present case previously became exacerbated 5 months after treatment with tocilizumab.

In conclusion, we experienced a case of CD-associated $\mathrm{MN}$ in which tocilizumab was effective for reducing proteinuria. Further reports should be accumulated to determine why patients with $\mathrm{CD}$ can present secondary $\mathrm{MN}$ as a renal complication, and why tocilizumab can reduce proteinuria in $\mathrm{CD}$-associated $\mathrm{MN}$.

\section{Abbreviations \\ CD: Castleman's disease (CD); CRP: C-reactive protein; IL-6: Interleukin-6; MCD: Multicentric CD; MPGN: Membranoproliferative glomerulonephritis; TMA: Thrombotic microangiopathy; UCD: Unicentric CD; VEGF: Vascular endothelial growth factor}

\section{Acknowledgements}

Not applicable.

\section{Authors' contributions}

$\mathrm{RS}, \mathrm{KK}, \mathrm{YH}, \mathrm{KO}, \mathrm{MF}, \mathrm{TM}$ and $\mathrm{AN}$ participated in the acquisition of clinical data. $\mathrm{RS}, \mathrm{KK}, \mathrm{AN}$, and KD carried out analysis of patient's clinical course and data interpretation. RS and KK wrote a draft of the manuscript and $\mathrm{YH}, \mathrm{KO}, \mathrm{MF}$, $T M, A N$, and $K D$ revised it critically. All authors read and approved the final manuscript.

\section{Funding}

Not applicable.

\section{Availability of data and materials}

The datasets used and/or analysed during the current study are available from the corresponding author on reasonable request.

\section{Declarations}

Ethics approval and consent to participate

Not applicable.

\section{Consent for publication}

Written informed consent was obtained from the patient for the publication of this Case report. A copy of the written consent is available for review by the editor of this journal.

\section{Competing interests}

The authors declare that they have no competing interests.

\section{Author details}

'Department of Cardiology and Nephrology, Mie University Graduate School of Medicine, 2-174 Edobashi, Tsu, Mie 514-8507, Japan. ${ }^{2}$ Center for Rheumatic Diseases, Mie University Hospital, Tsu, Japan.

Received: 26 October 2020 Accepted: 3 June 2021

Published online: 09 June 2021

\section{References}

1. Castleman B, Iverson L, Menendez VP. Localized mediastinal lymphnode hyperplasia resembling thymoma. Cancer. 1956;9:822-30.

2. Talat N, Belgaumkar AP, Schulte KM. Surgery in Castleman's disease: a systematic review of 404 published cases. Ann Surg. 2012;255:677-84.

3. Fajgenbaum DC, Uldrick TS, Bagg A, Frank D, Wu D, Srkalovic G, et al. International, evidence-based consensus diagnostic criteria for HHV-8negative/idiopathic multicentric Castleman disease. Blood. 2017;129:1646-57.

4. Yuan XG, Hu W, Chen FF, Huang BF, Zhao XY. Renal complications of Castleman's disease: report of two cases and analysis of 75 cases. Clin Exp Nephrol. 2011;15:921-6.

5. El Karoui K, Vuiblet V, Dion D, Izzedine H, Guitard J, Frimat L, et al. Renal involvement in Castleman disease. Nephrol Dial Transplant. 2011;26:599-609.

6. Liu AY, Nabel CS, Finkelman BS, Ruth JR, Kurzrock R, van Rhee F, et al. Idiopathic multicentric Castleman's disease: a systematic literature review. Lancet Haematol. 2016;3:e163-75.

7. Xu D, LV J, Dong Y, Wang S, Su T, Zhou F, et al. Renal involvement in a large cohort of Chinese patients with Castleman disease. Nephrol Dial Transplant. 2012;27(Suppl 3):iii119-25.

8. Hagihara K, Nishikawa T, Isobe T, Song J, Sugamata Y, Yoshizaki K. IL-6 plays a critical role in the synergistic induction of human serum amyloid a (SAA) gene when stimulated with proinflammatory cytokines as analyzed with an SAA isoform real-time quantitative RT-PCR assay system. Biochem Biophys Res Commun. 2004:314:363-9.

9. Mutneja A, Cossey LN, Liapis H, Chen YM. A rare case of renal thrombotic microangiopathy associated with Castleman's disease. BMC Nephrol. 2017;18:57.

10. Eremina V, Jefferson JA, Kowalewska J, Hochster H, Haas M, Weisstuch J, et al. VEGF inhibition and renal thrombotic microangiopathy. N Engl J Med. 2008;358:1129-36.

11. Leurs A, Gnemmi V, Lionet A, Renaud L, Gibier JB, Copin MC, et al. Renal pathologic findings in TAFRO syndrome: is there a continuum between thrombotic Microangiopathy and Membranoproliferative glomerulonephritis? A case report and literature review. Front Immunol. 2019;10:1489.

12. Weisenburger DD. Membranous nephropathy. Its association with multicentric angiofollicular lymph node hyperplasia. Arch Pathol Lab Med. 1979;103:591-4.

13. Ruggieri G, Barsotti P, Coppola G, Spinelli C, Balducci A, Ventola FR, et al. Membranous nephropathy associated with giant lymph node hyperplasia: a case report with histological and ultrastructural studies. Am J Nephrol. 1990;10:323-8.

14. Komaba H, Nakazawa T, Yamaguchi Y, Kumagai S, Fukagawa M. Interleukin6 receptor inhibition with tocilizumab in various renal involvements associated with multicentric Castleman's disease: a report of three cases. NDT Plus. 2008;1:423-6.

15. Tazi I, Rachid M, Quessar A, Benchekroun S. A rare association of Castleman's disease and nephrotic syndrome. Saudi J Kidney Dis Transpl. 2011;22:116-9.

16. Sun PP, Yu XJ, Wang SX, Zhou XJ, Qu L, Zhang F, et al. Association of vascular endothelial growth factor and renal thrombotic microangiopathy-like lesions in patients with Castleman's disease. Nephrology (Carlton). 2020;25:125-34.

17. Furutera N, Fukunaga N, Okita J, Suzuki T, Suenaga $Y$, Oyama $Y$, et al. Two cases of idiopathic multicentric Castleman disease with nephrotic syndrome treated with tocilizumab. CEN Case Rep. 2021:10:35-41.

18. lijima T, Hoshino J, Suwabe T, Sumida K, Mise K, Kawada M, et al. Tocilizumab for AA amyloidosis after treatment of multicentric Castleman disease with steroids, chemotherapy and rituximab for over 20 years. Intern Med. 2015;54:3215-9.

\section{Publisher's Note}

Springer Nature remains neutral with regard to jurisdictional claims in published maps and institutional affiliations. 